\title{
Impact of Non-life Insurance Penetration on the Economic Growth of Nigeria
}

\author{
BabaYaro Iyodo ${ }^{1} \quad$ Sunday Eneojo Samuel ${ }^{2 *} \quad$ Clement Adewole $^{1} \quad$ Patience Ote Ola $^{3}$ \\ 1.Department of Banking and Finance, University of Jos, Nigeria \\ 2.Department of Accounting, Business and Management, Abertay University, DD1 1HG, United Kingdom. \\ 3.Department of Accounting, Benue State University, Makurdi, Nigeria
}

\begin{abstract}
This study explores the impact of non-life insurance industry performance on economic growth in Nigeria. Insurance penetration is measured through five diverse proxies such as non-life insurance, savings, expenditures, investment and profits of the insurance industry with their time-series statistics covering the period 1988 and 2012. The ex-post facto research strategy and purposive (judgemental) sampling technique were discovered appropriate for the study as effectively utilised by several intellectuals in the past. Data were analysed using regression. The ordinary least square regression was adopted for the testing of the hypotheses. The outcomes of the study showed that non-life insurance penetration had a substantially positive effect on the economic growth in Nigeria during the period. Profit and investment are found to have a positive effect on the economy but statistically insignificant while Savings and government expenditure have an adverse effect on the economy. The study recommends an improved modification in insurance products, especially in non-life businesses to availing clients the chance of choosing from a diversity of products. The study, therefore, recommends an increase in the awareness of non-life insurance services for its impact to be felt at all levels and to encourage participation.
\end{abstract}

Keywords: Non-life insurance, Economic growth, Insurance penetration, Nigeria

DOI: $10.7176 /$ RJFA/11-2-05

Publication date: January $31^{\text {st }} 2020$

\section{Introduction}

In recent times, the insurance activity had shown an implausible increase which had an expressively valuable effect on the economic growth of several countries globally (Outreville, 2011; 2013). According to Avram, Nguyen and Skully (2010) and SwissRe (2015), total global insurance premiums have increased from $\$ 467$ billion to $\$ 3,426$ billion and \$3,732 billion in 1980, 2005 and 2006 respectively which amounts to approximately, 58\% and 42\% life and non-life insurance.

In addition, the capacity of insurance premium in the year 2009 rose to $\$ 4.06$ trillion, which is equal to $7 \%$ of global GDP. Subsequently, it increased to $\$ 4.3$ trillion and $\$ 4.57$ trillion in 2010 and 2011 (SwissRe, 2015) and \$4.61 and \$4.64 trillion in the year 2012 and 2013 respectively (Iyodo, Samuel and Inyada, 2018).

In Nigeria, the role of insurance companies cannot be under-estimated. It provides robust financial services that boost growth and progress in the country (Olulekan and Akinlo, 2013; Adeniyi, Adeyinka and Iyodo, 2019). Its services that influence growth in the country include the deployment of a colossal sum of funds by means of premiums for short- and long-term investment for development and underwriting of risk in economic entities. It also encourages financial reliability and confidence in the financial market and offers a sense of harmony to economic entities which in the long run, give rise to profit and value for the various shareholders involved (Ahmed, Ahmed and Ahmed, 2010; Avram, Nguyen and Skully, 2010; Charumathi, 2012).

Despite this achievement in the insurance sector, academic literature mostly, do not draw attention to these achievements instead more emphasis was laid on the other constituent of the sector, the financial sector which comprises of bank and the stock market. The insurance business has long been acknowledged as the risk-controlled service supplier in the financial sector. Undeniably the insurance company procedures are indispensable for the advancement of the banking sector, exclusively in secured (protected) lending. Also, Insurance nurtures trade across nations and subsequently produces bank proceeds.

Similarly, the involvement of insurance businesses in long-term premium flows encourages the improvement in home bond and stock exchanges markets (Philip, 2012; Din, Angappan and Baker, 2017). Chui and Kwot (2008), observe that banking and insurance activities are inseparable in many countries (Lim 2014). All these events impact promoting economic progress, and so provide the rationale for this study, the impact of non-life insurance penetration on the economic growth of Nigeria

Basically, insurance companies offer various sorts of products, however, it was largely agreed to categorize those services into two main groups: the life and the non-life insurance. The life insurance is the promise to compensate the beneficiary of the insured with certain sum of money upon his/her death, while the non-life insurance is not related to life but to property such as theft, motor vehicle insurance, marine insurance, property liability insurance, among others (Ajayi, 2002; Adaramola, 2002). The two groups of insurance products have diverse portions in risk management and indemnification, this study explores the impact of nonlife insurance 
infiltration on the economic growth of Nigeria

Due to the neglect of the insurance industry in Nigeria, carrying out business in Nigeria today is very risky considering the rate of insecurity in the country. Because of the uncertainty experienced in the country, the level of growth and economic advancement that should correspond with the country's enormous potential has not been achieved yet even in other developing countries.

One of the indices for measuring the progress of any economy is the size and maturity of its insurance industry. Insurance industry acts as the absorber of the risk and uncertainty associated with economic activities, and its absence can significantly reduce the growth of economic activity (Cristea, Marcu and Carstina, 2014). Most Nigerians especially the rural dwellers are ignorant of significant of the insurance industry. The part played by the insurance sector in easing sudden and ruinous occurrences thereby invigorating economic growth cannot be overemphasised (Guochen, 2012; Lee et al., 2016). Among its benefits, one of which is that it allows the insured to stabilise their income every time a negating event happens, or on the state in which such an incident does not take place, and this is done through the fee of premium and the receiving of compensation (Indemnity), in the case of misfortune (Seyed, et al., 2010; Olulekan, and Akinlo, 2013).

Despite the numerous achievement of the insurance sector as highlighted by Ahmed, Ahmed and Ahmed (2010); Avram, Nguyen and Skully (2010); Charumathi (2012), Iyodo, Samuel and Inyada, (2018), Adeniyi, Adeyinka and Iyodo (2019), and the neglect by the Nigeria government in utilizing the full potential of the sector, the question now is 'to what extent has non- life insurance infiltration exert a positive and substantial influence on economic growth of Nigeria?' The following hypothesis was formulated to answer the above question: Non- life insurance penetration does not have a positive and significant impact on economic growth in Nigeria.

For proper analysis, a period of 27 years (1988-2014) was reviewed to address the above examinable hypothesis. This research covers the best performing and quoted insurance companies both with the National Insurance Commission (NAICOM) and the Nigeria Stock Exchange (NSE). This study is significant because it provides information on the relationships between the insurance activity and the Nigerian economic growth, the performance and efficiency of the insurance industry which would be of great benefit to policymakers, insurers, economic watchers and the public, researchers and students.

\section{Review of Related Literature}

Although the insurance industry is an essential ingredient in the smooth working of the business entity and the entire Nigerian economy, it has not attracted much attention of many scholars.

Life is full of one form of risk or the other. One may choose not to be engaged in any business activity to avoid risk or loss, but as we all know, it is even riskier to do nothing. Virtually, every field of human endeavour is confronted with risk, in every decision taken either by individual or business organisation, one cannot but perceive the omnipresent nature of uncertainty particularly in the Nigerian business environment. This notwithstanding, one cannot avoid deciding from time to time since this is inseparable from life.

Osoka, (1999) and Beck and Webb (2003), maintain that the insurance business is necessary to the good and smooth running of a modern economy. According to Osipita (2009), the insurance business is vital to the financial market due to its role in helping businesses to manage their resources and alleviate risk efficiently. The supports also include helping small and medium scale entrepreneurs in taking inventive and higher-return projects (CEA, 2007). Arena (2008), emphasizes that there are possible to be diverse aspects of economic growth from the insurance products given that these products protect the firms, households, and individuals, from unlike kind of menaces that would affect the economic endeavour in different means.

Mittai and Gupta (2008), viewed insurance as a device of cooperation for spreading the loss caused by a risk over some individuals who are vulnerable to it and who agree to insure themselves against that risk. Insurance could be defined as an arrangement whereby one party promises to indemnify or pay another party a sum of money in the event of his suffering a specified loss or damage. It could also be defined as a system that makes available financial reimbursement for the effect of loss; the payment is created from the accrued contributions of all persons contributing to the fund or scheme (Anyaele, 2003; Zouhaier, 2014).

Economic growth is the process by which the productive dimensions of an economy rise over time, leading to an upsurge in its national income. When there is economic growth, its illustrated in the form of an income level, a rise in the overall capital stock, expansion of the labour force and in a higher volume of trade and consumption of the country.

\subsection{Insurance and Economic growth}

Several scholarships on insurances and economic growth have found the necessary evidence to recommend that the expansion of the insurance business is associated with economic growth (Webb, 2000; Ward and Zubruegg, 2000; Ebitu, Ibok and Mbum (2012); Iyodo, Samuel and Inyada, 2018). Insurance has gained growing importance through the quest for individuals and groups to control their income and life risks. In the view of Ujunwa and Modebe (2011), the insurance industry is perceived as the pillar of any country's risk management system since it 
guarantees financial haven and helps as an essential factor in the financial intermediation chain offering an organized spring of enduring capital for infrastructural developments.

One of the pioneering works on the relationship between insurance and economic growth is the work of Beenstock, Dickinson and Khajurja (1988), using time series data from 1970 to 1981 of ten advanced countries, which found that insurance has a positive influence on economic growth. In addition, Ward and Zurbruegg (2000), Hussels, Ward and Zurbruegg (2005) and Arena (2008) investigated how insurance (both life and non-life) promotes growth in an economy. The outcome of the studies further confirms a positive impact between the two variables. Arena (2008) investigation was based on looking at the relationship between 56 established and emerging countries using data from 1976 to 2008 whereas the Ward and Zurbruegg (2000) were based on OECD nations.

In addition to Ward and Zurbruegg (2000), Browne, Chung and Frees (2000), used a pooled cross-sectional panel model approach to examine the link between a general liability insurance and motor vehicle insurance in the OECD nations over the 1986-1996 period. They regressed liability insurance consumption on a diversity of factors, as well as the legal system, wealth and income. Browne, Chung and Frees (2000) argued that income influence insurance consumption. Relationship with risk aversion was statistically unimportant for motor vehicle insurance consumption and adversely related general liability insurance consumption. Also, Chang et al. (2014) examined the association between insurance and economic growth for 10 OECD nations. The bootstrap Granger causality model was used in the study and the revealed that one-way Granger causality shows that insurance business influence economic growth in countries France, United Kingdom, Japan, Switzerland, and the Netherlands (Kyosevski, 2011; Iyodo, Samuel and Inyada, 2018).

In addition, using a cross country dataset from 1980 to 1996 for 55 countries, Web, Grace and Skipper (2002) unearthed a positive association between economic growth and insurance. Similarly, Haiss and Sumegi (2008) examined the theoretical and empirical characteristics of the relationship between insurance and economic growth in 29 European nations. Using the regression analysis and panel data from the period 1992 to 2005, the study revealed that insurance influences the economic growth of nations positively, however, nonlife insurance has more impact. Similarly, Ege and Bahadir (2011) found an important and positive relationship between insurance and economic growth in of nations.

Supplementary studies such as Kugler and Ofoghi (2005), Vadlamannati (2008), Han et al. (2010); Curak, Loncar and Poposki (2009), Avram, Nguyen and Skully (2010); Ghosh (2013); Horng et al. (2012), and Akinlo and Apanisile (2014) have also explored the link between insurance and economic growth in various countries and found a significant and positive relationship between the variables. Also, a current study by Din, Angappan and Baker (2017) narrowed the studies to China, India, Malaysia, United States, United Kingdom, and Pakistan using ARDL approach. The result exposed a positive and significant relationship between total insurance and economic growth for the countries above but a negative between insurance and economic growth exist for Pakistan in relation to the variable, international trade.

Pradhan et al (2016) studied the links between insurance penetration, market capitalization, broad money and economic growth in South East Asian nations using data from 1988 to 2012. The study uses the Granger causality approach, the study found that insurance penetration and economic growth are cointegrated. Other studies on money supply and economic growth are Al-Yousif (2002), Calderon and Liu (2003), Chow and Fung (2011), and Hsueh et al. (2013). Al-Yousif (2002) studied 30 emerging nations and the study covers the period 1970 to 1999. The areas studied for Calderon and Liu (2003) is 109 countries and from 1960 to 1994 while Chow and Fung (2011) and Hsueh et al. (2013) covers 69 countries and 10 Asian countries, and 1970- 2004 and 1980-2007 respectively.

Related studies on market capitalization and economic growth as stated by Pradhan et al. (2016) are Dritsaki and Dritsaki-Bargiota (2005), covering the country Greece from 1988 to 2002; Enisan and Olufisayo (2009), 7 sub-Saharan African countries and from 1980 to 2004; Hou and Cheng (2017), Taiwan and from 1971 to 2004. Peia and Roszbach (2015) covering 22 advanced countries and from 1965 to 2011; Pradhan et al. (2016), 16 Asian countries and from 1988 to 2012. Rousseau and Xiao (2007), China and from 1995 to 2005.

\subsection{Theories of insurance and economic growth}

\subsubsection{Financial Liberalization Theory}

The revolutionary works of Patrick (1966), McKinnon (1973) and Shaw (1973) gave birth to the financial liberalisation theory which centres on jettisoning constraints on financial market and institutions, or when novelty advancements are introduced into the financial markets system to enhance growth in the economy (Arestis, Nissanke and Stein, 2005; Iacoviello and Minetti, 2003). After the seminar publication of Patrick (1966) on two possible associations, "demand-following" technique, in which financial progress in a country rises as the economy advances, and a "supply-leading" technique, in which the general growth of financial establishments leads to economic development, a substantial amount of studies have revealed a beneficial association between financial liberalisation and economic growth. Arestis, Nissanke and Stein (2005), states that the relationship between 
financial development and economic growth has received a great deal of attention throughout the modern history of economics.

\subsubsection{Circuit Theory}

Bossone (1998 and 2001), in articulating the circuit theory of finance incorporated a microeconomic dimension into the theory. Central to the circuit process is the complementary functions of banks and non-banking financial intermediaries in originating money and making it circulate in a manner beneficial to all agents. The effect is that those financial systems where money and capital markets functions are segmented but fundamental as in many emerging economies are susceptible to circuit malfunctioning and instability. Rajan and Zingales (1998), pointed out that it is the availability of investment opportunities that drive growth.

The scholars added that the extended advancement of financial markets facilitated the export growth of sectors reliant on external finance and resolved that the linkage between financial development and growth is one byproduct of the theory of financial markets and institutions, which reduce the cost of external finance for firms. A sound financial structure is an engine that drives economic performance through entrepreneurship growth as noted by Schumpeter (1934).

Others like Goldsmith (1969), Mckinnon (1973), and Shaw(1973), also acknowledged this view through the positive response of savings to the interest rate. Greenwood and Jovanovic (1990), established a model in which financial structure and economic performance are endogenously determined. The scholars highlighted that by pooling individual investment risk and remove uncertainty about the rate of return, the financial structure could stimulate faster economic progress.

\subsubsection{Kaldor's Model of Economic Growth}

The Kaldor model is an attempt to make savings-income ratio a variable in the economic growth process. It is based on the classical savings function which implies that savings, (premiums) generated by insurance companies equals the ratio of profit contributed to the national income or national output. The interpretative value of this model, according to Kaldor (1966), is the conceptualisation or treating of investment or the ratio of investment to output (I/Y) as an independent variable. An upsurge in the level of investment would raise the demand level, prices and income (Mongale and Tafadzwa, 2018).

\section{Material and Method}

The ex-post facto study strategy and the purposive sampling procedure was adopted for the study. This is the approach that establishes the causal relationship between the dependent and independent variables and participants are not randomly assigned. Purposive sampling technique is used to meet a particular need based on judgement (Onwumere, 2005; Samuel and Iyodo, 2011; Adebisi and Samuel, 2012). A secondary source of was also adopted because it falls within the objectives and hypothesis formulated for the study which is believed reliable and accessible documents for assessing the relationship between the non-life insurance industry and the Nigerian economy. The sources are NAICOM and CBN Statistical Bulletin.

\subsection{Model Specification}

This study is mainly quantitative and builds on existing studies and methodologies. The analytical procedures adopted in this study to test the hypothesis are as follows: multiple regression models, descriptive statistics, unit root test and ordinary least squares. The above methods are used mainly to avoid some challenges which include the issue of subjecting and bias of responses and relationships between variables.

In this study, the model is detailed in line with the works of Oke (2012), Curak, Loncar and Poposki (2009), ward and Zurbruegg (2000), Kugler and Ofoghi (2005). In the analysis of insurance sector development and economic growth in Nigeria by Oke (2012), using a modified model used by Curak, Loncar and Poposki (2009), the study used the Gross domestic product growth rate (GDPGR) at the market price as the dependent variable and for the explanatory variables, Oke (2012) added a number of Insurance Companies in Nigeria (NIC) and Total Insurance Investment (TII) into the modified model.

The model is however modified in this study by using the Gross Domestic Product growth rate (GGR) as dependable variable and by adding the following to the explanatory variables: Insurance penetration (non-life, savings, expenditures, investment and profits of the insurance industry with their time series data covering the period between 1988 and 2012.

Therefore, the model for this study, given the stated hypothesis can be specified as thus:

Non-life insurance business does not have a significant positive effect on the Nigerian economic growth;

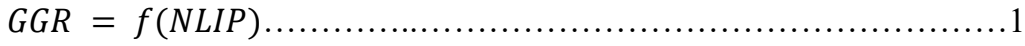

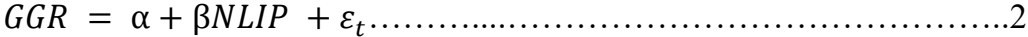

Where: GGR denotes gross domestic product growth rate and NLIP, Non-life Insurance penetration and $\varepsilon_{t}$, the error term

Introducing other control variables, we have:

$$
G G R_{t}=\beta_{0}+\beta_{1} N L I P_{t}+\beta_{2} G S A V_{t}+\beta_{3} G E X P_{t}+\beta_{4} P R O F_{t}+\beta_{5} I N V_{t}++\varepsilon_{t} \ldots \ldots \ldots \ldots . . .3
$$


The log-linear model used goes thus:

$$
L G G R_{t}=\beta_{0}+\beta_{1} L N L I P_{t}+\beta_{2} L G S A V_{t}+\beta_{3} L G E X P_{t}+\beta_{4} L P R O F_{t}+\beta_{5} L I N V_{t}+\varepsilon_{t} \ldots \ldots .4
$$

Where; GGR denotes Growth rate of the gross domestic product; NLIP, Non-Life Insurance penetration; GSAV, Savings; INV for Investments GEXP stand for Expenditure; PROF represent Profits of the Insurance industry, and $\varepsilon_{t}$ represents the error term. $\beta_{0}, \beta_{1}, \beta_{2}, \beta_{3}, \beta_{4}, \beta_{5}$ are the intercept and coefficients of independent variables.

The Gross Domestic Product Growth Rate (GRR) refers to the percentage change in a country's gross domestic product (GDP) when compared with the previous or the preceding year. It is significant for this study because it has been able to take care of the supposed effects of other economic variables beginning with the inflation rate. This is a slight departure from the study of Njegomir and Stojic (2010), Ward and Zurbruegg (2000) and Holsboer (1999), where they made use of the per capita gross rate of Nigeria's gross domestic product as their dependent variable in their studies.

Non-life Insurance Penetration (NLIP) is an Insurance business that does not deal with life. Using Beenstock, Dickinson and Khajuria (1988) and Outreville (1990) and this study adopt the total non-life premium. Profit of Insurance Industry (PROF) refers to the total profit generated by the insurance industry in a year. Profit of Insurance industry is obtained by deducting total expenditure from total income. This measure will be consistent with the works of Zhuo and Adams (2004) who explored the influence of life insurance and non-life insurance on the growth process of China.

Government expenditure (GEXP) which represent the amount of money spent by the government of a nation on providing goods and services for the nation such as education (Njegomir and Stojic, 2010). Government Savings (GSAV) Government's total savings are used by the government to help on the rainy days. It will be used as a proxy and as a central variable to measure the level of economic growth. Investment (INV) here refers to the total investment in the insurance business. It shows the level of the nation's growth. The higher the investment, the healthier the growth of that nation.

The direction and robustness of the analysis of the study would be determined through the unit root tests. EViews version 10 was utilized in carrying out the tests to determine the order of integration and incidence of unit root on the variables. Graphical presentation of the variables was also carried to confirm the unit root result and further examinations (see Table 1 and Figure 1 for unit root and graphical presentation results). All variables are in their $\log$ form.

From Table 1, the variables are integrated to the order of one (1) and zero (0), no variable is integrated to order of two (2) which automatically suggest the use of ARDL bound test approach for the study. The justification for the use of ARDL is established when variables are integrated of different orders ranging from level to first difference or both but not including second difference (Pesaran and Shin, 1998; Pesaran et al., 2001; Narayan, 2003, 2004; Duasa, 2007). ARDL method to Cointegration will give a perfect, accurate and efficient estimation of variables especially when their unit-roots results show a mixture of variables being stationary at level and first differences (Atif et al., 2010; Giles, 2013; Iheanacho, 2016; Marques et al., 2016; Olayungbo and Adediran, 2017). When all the variables are integrated to the order of zero, the regression will be more appropriate (Nkoro and Uko, 2016).

However, the dependent variable (LGGR) turned out to be stationary at levels which suggest the subject under investigation is stable. This also suggests the regression model will be applied here because the dependent variable should only be integrated to the order of 1 for ARDL to be applied (Pesaran et al., 2001; Giles, 2013).

From Figure 1, the variables are trending except for GGR reverting around the mean, thus implies that variable GRR is stationary at levels which confirms the result of the unit-roots in Table1.

\section{Result and Discussion}

Table 1 below presents the unit root result of the variables while Figure 1 presents the graphical presentation of variables. Table 1 and Table3 show the descriptive statistics result and regression analysis result carried out on the hypothesis earlier formulated for the study. 
Table 1: Unit root result

\begin{tabular}{|c|c|c|c|c|c|c|c|c|c|}
\hline \multirow[t]{2}{*}{ Variables } & & \multicolumn{4}{|c|}{ ADF } & \multicolumn{4}{|c|}{ PP } \\
\hline & & I & OT & I\&T & OT & I & $\overline{\text { OT }}$ & I\&T & $\overline{\text { OT }}$ \\
\hline LGGR & $\begin{array}{l}\text { Levels } \\
\Delta\end{array}$ & $\begin{array}{l}-4.5618 \\
(0.0013) \\
-8.7865 \\
(0.0000)\end{array}$ & $\mathrm{I}(0)$ & $\begin{array}{l}-5.6935 \\
(0.0005) \\
-8.2437 \\
(0.0000)\end{array}$ & $\mathrm{I}(0)$ & $\begin{array}{l}-4.5568 \\
(0.0013) \\
-19.9941 \\
(0.0001)\end{array}$ & $\mathrm{I}(0)$ & $\begin{array}{l}-6.6967 \\
(0.0000) \\
-21.4832 \\
(0.0000)\end{array}$ & $\mathrm{I}(0)$ \\
\hline LGEXP & $\begin{array}{l}\text { Levels } \\
\Delta\end{array}$ & $\begin{array}{l}-2.7788 \\
(0.0751) \\
-5.6398 \\
(0.0001)\end{array}$ & $\mathrm{I}(1)$ & $\begin{array}{l}-2.2676 \\
(0.4356) \\
-6.3550) \\
(0.0001)\end{array}$ & $\mathrm{I}(1)$ & $\begin{array}{l}-3.1330 \\
(0.0364) \\
-5.6092 \\
(0.0001)\end{array}$ & $\mathrm{I}(0)$ & $\begin{array}{l}-2.2676 \\
(0.4356) \\
-6.3723 \\
(0.0001)\end{array}$ & $\mathrm{I}(1)$ \\
\hline LINV & $\begin{array}{l}\text { Levels } \\
\Delta\end{array}$ & $\begin{array}{l}-0.4788 \\
(0.8798) \\
-2.9596 \\
(0.0508)\end{array}$ & $\mathrm{I}(1)$ & $\begin{array}{l}-2.0913 \\
(0.5254) \\
-2.8634 \\
(0.0190)\end{array}$ & $\mathrm{I}(1)$ & $\begin{array}{l}0.0052 \\
(0.9508) \\
-3.0211 \\
(0.0465)\end{array}$ & $\mathrm{I}(1)$ & $\begin{array}{l}-1.9523 \\
(0.5989) \\
-2.9283 \\
(0.0171)\end{array}$ & $\mathrm{I}(0)$ \\
\hline LNLIP & $\begin{array}{l}\text { Levels } \\
\Delta\end{array}$ & $\begin{array}{l}0.0228 \\
(0.9525) \\
-4.0359 \\
(0.0048)\end{array}$ & $\mathrm{I}(1)$ & $\begin{array}{l}-1.0691 \\
(0.9153) \\
-4.0329 \\
(0.0208)\end{array}$ & $\mathrm{I}(1)$ & $\begin{array}{l}-0.1123 \\
(0.9380) \\
-4.3147 \\
(0.0017)\end{array}$ & $\mathrm{I}(1)$ & $\begin{array}{l}-1.3594 \\
(0.8490) \\
-4.0034 \\
(0.0221)\end{array}$ & $\mathrm{I}(1)$ \\
\hline LPROP & $\begin{array}{l}\text { Levels } \\
\Delta\end{array}$ & $\begin{array}{l}-4.2947 \\
(0.0033) \\
-3.4531 \\
(0.0204)\end{array}$ & $\mathrm{I}(0)$ & $\begin{array}{l}-3.3443 \\
(0.0853) \\
-4.8402 \\
(0.0047)\end{array}$ & $\mathrm{I}(1)$ & $\begin{array}{l}-1.2292 \\
(0.6459) \\
-7.9542 \\
(0.0000)\end{array}$ & $\mathrm{I}(1)$ & $\begin{array}{l}-2.6899 \\
(0.2482) \\
-10.4151 \\
(0.0000)\end{array}$ & $\mathrm{I}(1)$ \\
\hline LSAV & $\begin{array}{l}\text { Levels } \\
\Delta\end{array}$ & $\begin{array}{l}-0.0108 \\
(0.9492) \\
-4.0079 \\
(0.0052) \\
\end{array}$ & $\mathrm{I}(1)$ & $\begin{array}{l}-2.8605 \\
(0.1909) \\
-3.9350 \\
(0.0255) \\
\end{array}$ & $\mathrm{I}(1)$ & $\begin{array}{l}-0.0108 \\
(0.9492) \\
-3.9979 \\
(0.0053) \\
\end{array}$ & $\mathrm{I}(1)$ & $\begin{array}{l}-2.4606 \\
(0.3430) \\
-3.9181 \\
(0.0264) \\
\end{array}$ & $\mathrm{I}(1)$ \\
\hline
\end{tabular}

Note: Values in the bracket, p-value; I, intercept; I\&T, intercept and trend; OT, Order of integration; $\Delta$, first difference.

Source: Authors' EViews Computation
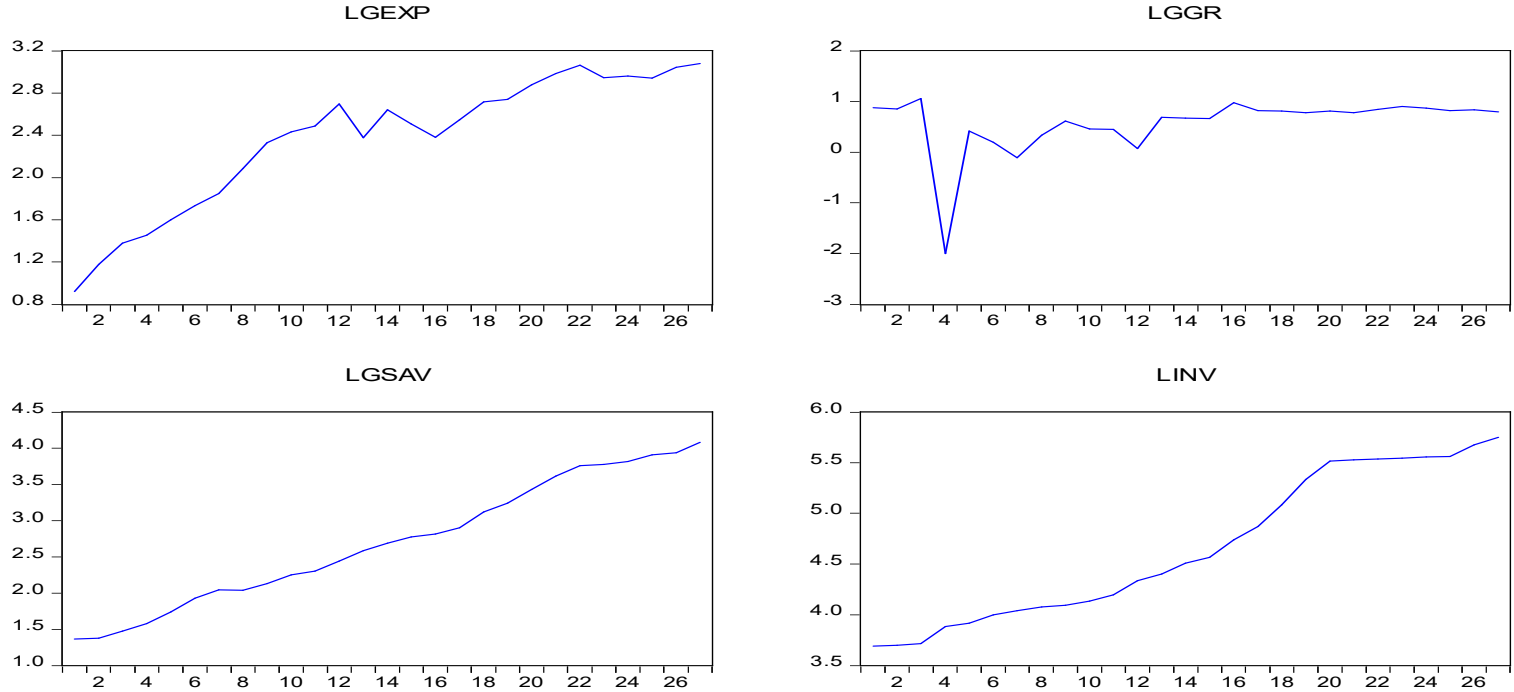

LNLIP
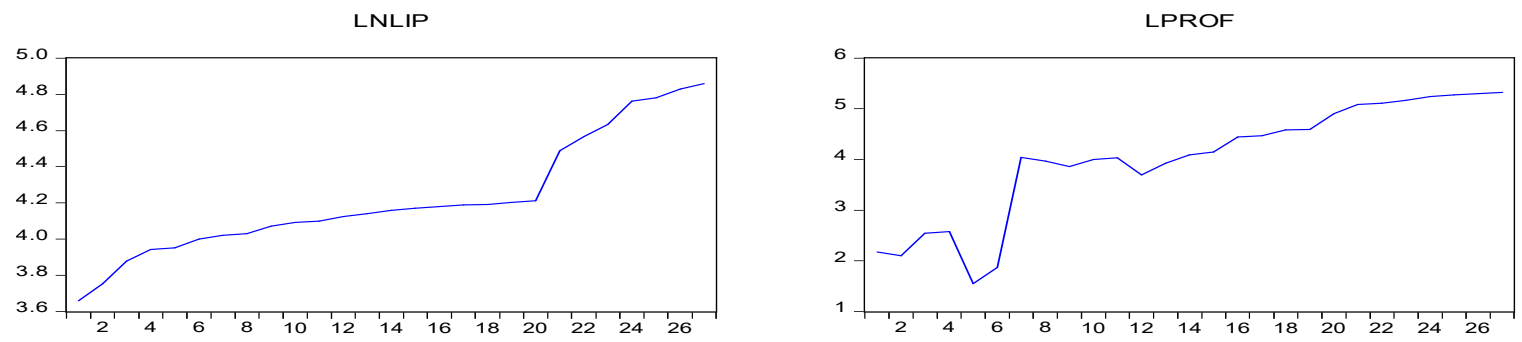

Figure 1: Graphical presentation of variables 
Table 2: Descriptive Statistics Result

\begin{tabular}{|l|r|r|r|r|r|r|}
\hline Year & \multicolumn{1}{|l|}{ LGR } & \multicolumn{1}{l|}{ LNLIP } & \multicolumn{1}{l|}{ LGSAV } & \multicolumn{1}{l|}{ LGEXP } & \multicolumn{1}{l|}{ LPROF } & \multicolumn{1}{l|}{ LINV } \\
\hline Mean & 0.566827 & 4.221544 & 2.707786 & 2.368934 & 4.000971 & 4.664938 \\
\hline Median & 0.780317 & 4.159077 & 2.688464 & 2.507046 & 4.090970 & 4.507280 \\
\hline Maximum & 1.055378 & 4.857226 & 4.079478 & 3.081491 & 5.318871 & 5.751068 \\
\hline Minimum & -2.000000 & 3.659308 & 1.366423 & 0.919078 & 1.549003 & 3.689948 \\
\hline Std. Dev. & 0.584995 & 0.325210 & 0.871759 & 0.629277 & 1.144594 & 0.725192 \\
\hline Skewness & -3.321152 & 0.623358 & 0.047422 & -0.823494 & -0.770397 & 0.196054 \\
\hline Kurtosis & 14.95673 & 2.537369 & 1.739272 & 2.546739 & 2.472269 & 1.477178 \\
\hline Jarque-Bera & 210.4689 & 1.989371 & 1.798234 & 3.282765 & 2.984116 & 2.781826 \\
\hline Probability & 0.000000 & 0.369840 & 0.406929 & 0.193712 & 0.224909 & 0.248848 \\
\hline Sum & 15.30434 & 113.9817 & 73.11021 & 63.96122 & 108.0262 & 125.9533 \\
\hline Sum Sq. Dev. & 8.897706 & 2.749803 & 19.75907 & 10.29574 & 34.06246 & 13.67349 \\
\hline Observations & 27 & 27 & 27 & 27 & 27 & 27 \\
\hline
\end{tabular}

Source: Authors' E-views Computation

For Non- life insurance penetration (NLIP), the mean within is 4.2215 while the medium value was 4.1591. Non-life Life insurance penetration in Nigeria is highest in 2011 when the value is 4.8572 while the year with the minimum life insurance penetration was in 1988 when the value was N3.6593. As uncovered by the skewness (0.6234) of Non-life insurance penetration signifying that the extent of departure from the mean of the distribution is positive showing that in general, there was a steady increase in non-life insurance activities/penetration from 1988 to 2014. The Jarque-Bera statistic which shows the normality of distributions is 1.9894 and since the probability of $0.3698(37 \%)$ is greater than $5 \%$ significant level, the distribution is normally distributed. The JB criteria is to reject the null or any value above 0.05 which implies accepting the alternate, there is, normality is found in the data (Jarque and Bera, 1980).

Table 3: Regression Result ${ }^{\mathrm{a}}$

\begin{tabular}{|l|r|r|r|r|}
\hline Variables & Coefficient & Std Error & t-statistics & Prob \\
\hline LNLIP & 4.523065 & 0.733974 & 7.971760 & 0.00 \\
\hline LGSAV & -65.13234 & 26.43255 & -3.265410 & 0.01 \\
\hline LGEXP & -70.04228 & 69.72787 & -1.291313 & 0.22 \\
\hline LPROF & 0.923520 & 0.917443 & 0.673289 & 0.38 \\
\hline LINV & 0.262278 & 0.213713 & 1.325101 & 0.42 \\
\hline C & 321515.4 & 23144.00 & 9.923451 & 0.00 \\
\hline $\mathrm{R}^{2}=0.9684 ;$ & $\mathrm{AR}^{2}=0.9521 ;$ & DW=1.9345; & AIC 23.2876; \\
$\mathrm{SIC}=23.5773 ;$ & F-Stat $=123.5125 ;$ & Prob (F-Stat) $=0.00000$ & \\
\hline
\end{tabular}

$$
a=\text { dependent variable }=L G G R
$$

$L G G R_{t}=\beta_{0}+\beta_{1} L N L I P_{t}+\beta_{2} L G S A V_{t}+\beta_{3} L G E X P_{t}+\beta_{4} L P R O F_{t}+\beta_{5} L I N V_{t}+\varepsilon_{t} \ldots \ldots \ldots \ldots \ldots \ldots \ldots . \ldots \ldots$

$L G G R=321515.4+4.523065 L N L I P-65.13234 L G S A V_{t}-70.04228 L G E X P_{t}+0.923520$ LPROF $_{t}+$ $0.262278 \operatorname{LINV}_{t}+\varepsilon \quad 6$

The table above shows the outcome of the regression analysis of the study from 1988 to 2014 . The result reveals that the model for our study is fit $($ F-statistic $=123.51)$ with a probability of 0.00000 . The coefficient of determination $\left(\mathrm{R}^{2}\right)$, which gauges the goodness of fit of the model, shows that the explanatory variables described $97 \%$ of the differences observed in the dependent variable. This was regulated by the Adjusted $\mathrm{R}^{2}$ to $95 \%$, demonstrating that there are other variables excluding the regressors that might likewise influence the dependent variable. The result shows that LNLIP has a positive and substantial impact on the LGGR of Nigeria (LNLIP coefficient $=4.52, \mathrm{p}=0.00<0.05, \mathrm{t}$-value $=7.9717)$. The control variable, LGSAV, has negative but significant impact on LGGR (LGSAV coefficient $=-65.13, p=0.01<0.05$, $\mathrm{t}$-value $=-3.27$ ). Also, LGEXP had a negative but insignificant impact on LGGR (LGEXP coefficient $=-70.04, p=0.22>0.05$, t-value $=-1.29$ ). Likewise, LPROF had a positive but non-significant impact on LGGR (LPROF coefficient $=0.92, \mathrm{p}=0.38>0.05$, $\mathrm{t}$-value $=0.67$ ) while LINV had a positive and insignificant impact on LGGR (LINV coefficient $=0.26, p=0.42>0.05$, $\mathrm{t}$-value $=1.33$ ).

It is obvious from the result above that the null hypothesis is rejected and the alternate accept which specifies that non-life insurance penetration had a positive and significant impact on economic growth in Nigeria.

\section{Conclusion}

There is no reservation that the role of insurance which is summarized as intermediation, indemnification and risk transfer in an economy with regards to economic growth and development cannot be played down and at the same time, underestimated. No-life insurance premiums secure the lives and future of the people. It helped bring 
financial stability and promote economic development directly and indirectly in many nations including Nigeria. However, the role differs for diverse economic levels and principally depend on proxies used in gauging the insurance activity. this study examines the effect of non-life insurance penetration on the economic growth in Nigeria between 1988 to 2014 using five distinct proxies.

Results revealed that Non-life insurance has a positive and significant effect on the economic growth of Nigeria. Also, it shows that insurance profit and investment had a positive effect on the Nigerian economy but not expressively enough. On the other hand, savings and expenditure had an adverse effect on the economy. Although, savings influence is significant.

The positive and substantial impact of non-life insurance penetration on economic growth as revealed in the result submits that there has been an upward movement and advancement of nonlife insurance penetration in Nigeria. The study, therefore, recommends that more awareness should be created to boost the involvement of the product industry and firms as this will expand the activities of the insurance industry in Nigeria. Also, this study recommends an increased diversification of insurance products, especially in non-life businesses. The insurers should come up with new non-life products and adjustment of existing insurance products, thus availing customers the opportunity of choosing from a variety of products. There is also need for the insurance companies to take advantage of the non-life insurance products made compulsory by law to substantially increase their premium income and increase insurance penetration in the economy as this will foster economic growth in Nigeria.

\section{References}

Adaramola, A.O. (2002). The Nigeria Financials Sector, Libra Consult, Lagos.

Adebisi J.F. and Samuel S.E. (2012) 'Effects of taxes on dividend payout ratio of banks in Nigeria', Salem Journal of Management Science, College of Peace and Social Science, Vol. 1 No.1, pp.88-106.

Adeniyi, D.J., Adeyinka, A.J. and Babayaro, I. (2019) 'Insurance Companies and the Efficiency of Financial Intermediation in Nigeria', American International Journal of Economics and Finance Research, Vol. 1 No.1, pp.21-33

Ahmed, N., Ahmed, Z. and Ahmed, I. (2010) 'Determinants of capital structure: A case of life insurance sector of Pakistan', European Journal of Economics, Finance and Administrative Sciences, Vol. 24 No.24, pp.7-12.

Ajayi, L.A. (2000) Elements and scope of insurance, Hybrid Publishers Limited, Akure.

Akinlo, T. and Apanisile O.T. (2014) 'The relationship between insurance and economic growth in sub-Saharan African: A panel data analysis', Modern Economics, Vol. 5, pp.120-127

Al-Yousif, Y. (2002) 'Financial development and economic growth: another look at the evidence from developing countries', Review of Financial Economics, Vol. 11 No.2, pp.131-150.

Anyaele, J.U (2003) Comprehensive Economics for secondary school, A. Johnson Publishers, Lagos

Arena, M. (2008) 'Does insurance market promote economic growth? A cross-country study for industrialized and developing countries', Journal of Risk and Insurance, Vol. 75 No.4, pp.921-946.

Arestis, P., Nissanke, M. and Stein, H. (2005) 'Finance and development: Institutional and policy alternatives to financial liberalization theory’, Eastern Economic Journal. Vol. 31 No. 2, pp.245-263

Atif, R.M., Jadoon, A., Zaman K., Ismail, A. and Seemab, R. (2010) 'Trade liberalisation, financial development and economic growth: evidence from Pakistan (1980-2009)', Journal of International Academic Research, Vol.10 No 2, pp.30-37.

Avram, K., Nguyen, Y. and Skully, M. (2010) 'Insurance and economic growth: A cross-country examination (Working Paper)', Department of Accounting and Finance, Monash University, Clayton.

Beck, T. and Webb, I. (2003) 'Economic, demographic, and institutional determinants of life insurance consumption across countries', World Bank Economic Review, Vol.17 No.1, pp. 51-88.

Beenstock, M., Dickinson, G., and Khajuria, S. (1988) 'The relationship between property liability insurance premiums and income: An international analysis', Journal of Risk and Insurance, Vol. 55 No. 2, pp.259-272.

Bossone, B. (1998) Circuit theory of finance and the role of incentives in financial sector reform. The World Bank. Policy Research Working Papers, December

Bossone, B. (2001) 'Circuit theory of banking and finance', Journal of Banking and Finance Vol. 25 No.5, pp.857890.

Browne M.J., Chung J.W. and Frees, E.W. (2000) 'International property, liability insurance consumption', Journal of Risk and Insurance, Vol. 67 No. 1, pp.73-90.

Calderon, C. and Liu, L. (2003) 'The direction of causality between financial development and economic growth', Journal of Development Economics, Vol. 72 No 1, pp. pp.321-334.

CEA (Comité Européen des Assurances) (2007) European Insurance in Figures, CEA Statistics No. 24, 2006. Gefunden Am. 14

Chang T., Lee C.C. and Chang C.H. (2014) 'Does insurance activity promote economic growth? Further evidencebased on bootstrap panel Granger causality test', The European Journal Finance, Vol. 20 No.12, pp.11871210. 
Charumathi, B. (2012) 'On the determinants of profitability of Indian life insurers-an empirical study. In: Proceedings of the World Congress on Engineering 2012, London, pp.4-6.

Chow, W.W. and Fung, M.K. (2013) 'Financial development and growth: a clustering and causality analysis', The Journal of International Trade and Economic Development, Vol.22 No.3, pp.430-453.

Chui, A.C. and Kwok, C.C. (2008) 'National culture and life insurance consumption', Journal of International Business Studies, Vol.39 No.1, pp.88-101.

Cristea, M., Marcu, N. and Carstina S. (2014) 'The relationship between insurance and economic growth in Romania compared to the main results in Europe: a theoretical and empirical analysis', Procedia Economic Finance, Vol.8 No.14, pp.226-235.

Curak, M., Loncar, S. and Poposki, K. (2009) 'Insurance sector development and economic growth in transition countries', International Research Journal Finance and Economics, Vol.34 No.3 pp.29-41.

Din, S.M.U., Angappan, R. and Baker, A.A. (2017) 'Insurance effect on economic growth among economies in various phases of development', Review of International Business and Strategy, Vol.27 No.4, pp.501-519.

Dritsaki, C. and Dritsaki-Bargiota, M. (2005) 'The causal relationship between stock, credit market and economic development: empirical evidence for Greece', Economic Change and Restructuring, Vol.38 No.1, pp.113127

Duasa, J. (2007) 'Determinants of Malaysian trade balance: An ARDL bounds testing approach', Global Economic. Review, Vol.36 No.1, pp.89-102.

Ebitu, E.J., Ibok, N.I. and Mbum, P.A. (2012) 'Factors affecting insurance consumption in Akwa Ibom State, Nigeria', Journal of Research in International Business and Management, Vol.2 No.12, pp.323-328.

Ege, I. and Bahadir, T. (2011) 'The relationship between the insurance sector and economic growth: An econometric analysis' International Journal of Economic Research, Vol.2 No.2, pp.1-9.

Enisan, A.A. and Olufisayo, A.O. (2009) 'Stock market development and economic growth: Evidence from seven sub-Sahara African countries', Journal of Economics and Business. Vol. 61 No.2, pp.162-171.

Ghosh, A. (2013) 'Does life insurance activity promote economic development in India: An empirical analysis', Journal of Asia Business Studies, Vol.7 No.1 pp. 31-43.

Giles, D. (2013) 'ARDL Models-Part II-Bounds Tests' [online] Available from: davegiles.blogspot.com/2013/06/ardl-models-part-ii-boundstests.htm [Accessed 13 November 2018].

Goldsmith, R.W. (1969) Financial structure and development, Yale University Press, New Haven.

Greenwood, J. and Jovanovic, B. (1990) 'Financial development, growth, and the distribution of income', Journal of Political Economy, Vol.98 No.5, pp.1076-1107.

Guochen, P.N., and Chiwei, S.U. (2012) 'The relationship between insurance development and economic growth: A Cross-Regional Study for China' In: Z. Wenyuan (Ed.), China International Conference on Insurance and Risk Management (pp. 1-22). Qingdao: China Center for Insurance and Risk Management.

Haiss, P., and Sumegi, K. (2008) 'The relationship between insurance and economic growth in Europe: A theoretical and empirical analysis', Empirica Vol.35 No.4, pp.405-431.

Han, L., Li, D., Moshirian, F. and Tian, Y. (2010) 'Insurance development and economic growth' The Geneva Papers on Risk and Insurance Issues and Practice, Vol.35 No.2, pp.183-199.

Holsboer, J.H. (1999) 'Repositioning of the insurance industry in the financial sector and its economic role', The Geneva Papers on Risk and Insurance. Issues and Practice, Vol.24 No.3), pp.243-290.

Horng, M.S., Chang, Y.W., and Wu, T.Y. (2012) 'Does insurance demand or financial development promote economic growth? Evidence from Taiwan', Applied Economics Letters, Vol.19 No.2, pp.105-111.

Hou, H. and Cheng, S.Y. (2017) 'The dynamic effects of banking, life insurance, and stock markets on economic growth', Japan and the World Economies, Vol.41, pp.87-98

Hsueh, S., Hu, Y. and Tu, C. (2013) 'Economic growth and financial development in Asian countries: a bootstrap panel Granger causality analysis’ Economic Modelling, Vol.32: pp.294-301.

Hussels, S., Ward, D. and Zurbruegg, R. (2005) 'Stimulating the demand for insurance. Risk Management and Insurance Review, Vol.8 No.2, pp.257-278.

Iacoviello, M. and Minetti, R. (2003) 'Financial liberalization and the sensitivity of house prices to monetary policy: theory and evidence', The Manchester School, Vol. 71 No.1: pp.20-34

Iheanacho E. (2016) 'The impact of financial development on economic growth in Nigeria: An ARDL analysis', Economies. Vol.4 No.4, pp.1-12.

Iyodo, B.Y., Samuel, S.E. and Inyada, S.J. (2018) 'Effect of insurance industry performance on economic growth in Nigeria', International Journal of Business and Finance Management Research, Vol.6 No.3, pp.22-33

Jarque, C.M. and Bera, A.K. (1980) 'Efficient tests for normality, homoscedasticity and serial independence of regression residuals', Economics Letters, Vol.6 No.3, pp.255-259.

Kaldor, N. (1966) Causes of the Slow Rate of Economic Growth of the United Kingdom. An Inaugural Lecture, Cambridge University Press, London.

Kugler, M. and Ofoghi R. (2005) Does insurance promote economic growth? Evidence from the UK. Money Macro 
and Finance Research Group Conference, 13 September, University of Crete, Rethymno, Greece.

Kjosevski, J. (2011) 'Impact of insurance on economic growth: The case of Republic of Macedonia', European Journal of Business and Economics, Vol.4, pp.34-39.

Lee C.C., Lin C.W. and Zeng J. H. (2016) 'Financial liberalisation, the insurance market, and the likelihood of financial crises', Journal of International Money and Finance Vol.62 No. C, pp.25-51

Lim, H.H. (2014) 'Towards an integrated ASEAN insurance market-keynote address by Mr Lim Hng Kian, Minister for Trade and Industry, Deputy Chairman, Monetary Authority of Singapore. In: Inaugural ASEAN Insurance Summit, 1 October 2014. Singapore

Marques A.C., Fuinhas J.A. and Menegaki A.N. (2016) 'Renewable versus non-renewable electricity and the industrial production nexus: Evidence from an ARDL bound test approach for Greece', Renewable Energy, Vol.96, pp.645-655.

Mckinnon, R.I. (1973) Money and Capital in Economic Development, Brookings Institutions, Washington DC.

Mittai, A. and Gupta, S.L. (2008) Principles of Insurance and Risks Management, $2^{\text {nd }}$ Ed., Sultan Chard and Sons Publishers, New Delhi, India

Mongale, I. and Tafadzwa, M. (2018) 'Manufacturing sector and economic growth in South Africa: A time-series test of Kaldor's first growth law' In: $3^{\text {rd }}$ Annual International Conference on Public Administration and Development Alternatives. 04 - 06 July 2018, Stellenbosch University, Saldanha Bay, South Africa

Narayan, P.K. (2003) 'Tourism demand modelling: Some issues regarding unit-roots, co-integration and diagnostic tests', International Journal of Tourism Research, Vol.5 No.5, pp.369-380.

Narayan, P.K. (2004) 'Fiji's tourism demand: the ARDL approach to cointegration', Tourism Economics, Vol.10 No.2, pp.193-206.

Njegomir, V. and Stojic, D. (2010) 'Does insurance promote economic growth: The evidence from Ex-Yugoslavia region', Ekonomska Misao I Praksa, Vol.1, pp.31-48.

Nkoro, E. and Uko, A.K. (2016) 'Autoregressive Distributed Lag (ARDL) cointegration technique: application and interpretation', Journal of Statistical and Econometric Methods, Vol.5 No.4, pp.63-91

Oke, M. (2012) 'Insurance Sector Development and Economic Growth in Nigeria', African Journal of Business Management, Vol.6 No.23, pp.7016-7023.

Olayungbo, D.O. and Adediran, K.A. (2017) 'Effect of oil revenue and institutional quality on economic growth with an ARDL approach', Energy and Policy Research, Vol.4 No.1, pp.44-54.

Olulekan, Y. and Akinlo, T. (2013) 'Insurance development and economic growth in Nigeria, 1986-2010', Journal of Economics and International Finance, Vol.5 No.5, pp.218-224.

Onwumere J.U.J. (2005) Business and Economic Research Method. Don-Vinton Limited, Lagos.

Osipita, T. (2009) 'Legal Regulation of Insurance Business in Nigeria: Problems and Prospects', Chartered Insurance Institute of Nigeria Journal, Vol.11 No.1, pp.6-22

Osaka, O. (1992) Insurance and the Nigerian economy. Lagos: Abiola Press Limited

Osoka, O. (1999) 20 years of reinsurance in Nigeria. Nigeria Reinsurance Corporation

Outreville, J. F. 1990 'The economic significance of insurance markets in developing countries', Journal of Risk and Insurance, Vol.57 No.7, pp.487-498.

Outreville J.F. (2011) The relationship between insurance growth and economic development: 80 Empirical papers for a review of the literature (ICER Working Paper No.12/2011), HEC Montreal, Canada.

Outreville, J.F. (2013) 'The relationship between insurance and economic development: 85 empirical papers for a review of the literature', Risk Management and Insurance Review, Vol.16 No.1, pp.71-122.

Patrick, H.T. (1966) 'Financial development and economic growth in underdeveloped countries', Economic Development and Cultural Change, Vol.14 No.2, pp.174-189.

Peia, O. and Roszbach, K. (2015) 'Finance and growth: time series evidence on causality', Journal of Financial Stability, Vol.19, pp.105-118.

Pesaran, M.H., Shin, Y. and Smith, R.J. (2001) 'Bounds testing approaches to the analysis of level relationships', Journal of Applied Economics, Vol.16 No.3, pp.289-326.

Philip, C.O. (2012) 'Insurance market activity and economic growth evidence from Nigeria', Asian Economic and Financial Review, Vol.1 No.4, pp.245-253.

Pradhan, R.P., MakArvin, B., Morman, N.R., Nair, M., and Hall, J.H. (2016) 'Insurance penetration and economic growth nexus: cross-country evidence from ASEAN', Research in International Business and Finance, Vol.36, pp.447-458.

Rajan, R. and Zingales, L. (1998) 'Finance Dependence and Growth', The American Economic Review, Vol.88, pp.559-586.

Rousseau, P. L. and Xiao, S. (2007) 'Banks, stock markets, and China's 'great leap forward', Emerging Markets Review, Vol.8 No.3, pp.206-217.

Samuel S.E. and Iyodo B.Y. (2011) 'The effects of interest rates volatility on development stock: A time series analysis', Kogi State University Journal of Public Administration, Vol.1 No.1, pp.38-47. 
Schumpeter, J.A. (1934) Change and the Entrepreneur. Essays of JA Schumpeter

Seyed, A.S., Farahnaz, R.G., Seyed, A.S., Yaser, M., Omid, S., and Abass, A. (2010) 'Survey of effective factors on adoption of crop insurance among farmers: A case study of Behbahan County', African Journal of Agricultural Research, Vol.5 No.16, pp.2237-2242.

Shaw, E. (1973) Financial deepening in economic development, Oxford University Press, New York

Swiss Reinsurance Company (2015). Zurich: Sigma Publication, No. 5/2006.

Ujunwa, A. and Modebe, N.J. (2011). Repositioning the Insurance Industry for Operational Efficiency: The Nigerian Case. Journal of Applied Finance and Banking. 1(3):15-32.

Vadlamannati, K.C. (2008) 'Do insurance sector growth and reforms affect economic development? Empirical evidence from India', The Journal of Applied Economic Research, Vol.2 No.1, pp.43-86.

Ward, D. and Zurbruegg, R. (2000) 'Does insurance promote economic growth? Evidence from OECD countries', Journal of Risk and Insurance, Vol.67 No.4, pp.489-506.

Web, I., Grace, M.F. and Skipper, H.D. (2002) 'The effect of banking and insurance on the growth of capital and output', Center for Risk Management and Insurance working paper.

Web, I. (2000) The effect of Banking and Insurance on the growth of Capital. Unpublished Dissertation, Georgia State University, United State.

Zou, H. and Adams, M.B. (2006) 'The corporate purchase of property insurance: Chinese evidence', Journal of Financial Intermediation, Vol.15 No.2, pp.165-196.

Zouhaier, H. (2014) 'Insurance and economic growth', Journal of Economics and Sustainable Development, Vol.5 No.12, pp.102-113. 